\title{
The Perception of Non-Muslim Students On Educational Environment In Universitas Pendidikan Muhammadiyah Sorong
}

\author{
$1^{\text {st }} \operatorname{Jusmin}^{1}, 2^{\text {nd }}$ Mukhlas Triono ${ }^{2}$ \\ \{jusminjosse328@gmail.com ${ }^{1}$, mukhlas.zines.dad@gmail.com ${ }^{2}$ \}
}

Universitas Pendidikan Muhammadiyah Sorong, West Papua, Indonesia ${ }^{1,2}$

\begin{abstract}
This research aimed to; first, describe the background of perception of nonMuslim students toward the educational environment in Muhammadiyah Education University of Sorong, West Papua. Second, to explain the factor affecting the acceptance of non-Muslim students toward the educational environment in Muhammadiyah Education University of Sorong. Third, to elucidate the obstacle faced by non-Muslim toward the educational environment in Muhammadiyah Education University of Sorong, and fourth, regarding the efforts to overcome the obstacle. The procedures of this research consisted of three stages, namely the preparation of research instrument, the implementation of research, and the analysis of research results. The model of approach used in this research was a quantitative approach with non-Muslim students as the research subject. Data were collected through documentation and questionnaire techniques. Research results indicated that the responses of non-Muslim students' perception on educational environment in Muhammadiyah Education University of Sorong were categorized as good, the factor affecting the perception of non-Muslim students on educational environment in Muhammadiyah Education University of Sorong was the openness of Muhammadiyah Education University of Sorong toward non-Muslim students, the obstacle faced by nonMuslim students toward educational environment in Muhammadiyah Education University of Sorong was the tuition fees, the effort to overcome the obstacle faced by nonMuslim toward the educational environment in Muhammadiyah Education University of Sorong is through the establishment of policies regarding tuition fees by Muhammadiyah Education University of Sorong.
\end{abstract}

Keywords: Perception, Non-Muslim, Students, Educational Environment

\section{Introduction}

As one of the Universities of Muhammadiyah available in Papua, Muhammadiyah Education University of Sorong is the first and only university in West Papua which acquired B grade accreditation of institution. Muhammadiyah Education University of Sorong becomes more reliable, acknowledge, required, and made as the primary alternative by Papua and West Papua people. The presence of Muhammadiyah Education University of Sorong provides impacts on the growth and the adequate distribution of human resources who conceive keen and virtuous characters, care about the environment, dedicated, and persevere, adamant, and resilient, always prioritize public interests, sensitive to the community need, proficient in science and technology, innovative, and creative in solving problems, anticipative, and 
progressive toward future challenges. The presence of Muhammadiyah Education University of Sorong in Papua is certainly embracing the modern education model pioneered by the founder of Muhammadiyah-KH Ahmad Dahlan, which is not only devoted to establish the cadres of Muhammadiyah but also to educate children of the nation regardless of their backgrounds. This kind of preaching through education is emphasizing on transformations which are progressive, beneficial, truthful, just, and other primary values for the benefit and welfare of human lives without differentiating races, tribes, groups, religions, and others.

The empirical basis of this research was the gait of Muhammadiyah showed in Muhammadiyah Education University of Sorong which has given a new color for the term of "tolerance" that begins to fade in the motherland. Muhammadiyah Education University of Sorong will become a unique magnet for observers to find out how a tolerance is applied due to the strength of the element of mutual needs. The tolerance in Muhammadiyah Education University of Sorong becomes an interesting phenomenon because 60 percent of total 2,800 students are non-Muslim. During the new admission for new students in the past 2016/2017 academic year, 70 percent of new students were non-Muslim and the majority of them are native Papuan. This condition shows that the tolerance has been running in this university. Muhammadiyah Education University of Sorong has become a comfortable home for nonMuslims who are native Papuan and non-Papuan to seek for knowledge.

Some non-Muslim students stated that they feel comfortable and unburdened with the education environment which is apparently different with the religion they embrace. Moreover, this statement was supported by the argument of other non-Muslim students in which "it is very normal if Muhammadiyah Education University of Sorong as the Islam-based campus to obligate their students to take Islamic subjects because these subjects will give benefits for them although they are only the knowledge about Islam".

The arguments of initial informants are obviously unable to represent the opinions and arguments of the other non-Muslim students concerning the existence of educational environment for all students in the setting of Muhammadiyah Education University of Sorong.

Based on the description above, the researcher was interested to study the perception of non-Muslim students on educational environment. The researcher packed this research with "The Perception of Non-Muslim Students on Educational Environment in Muhammadiyah Education University of Sorong" as the title.

According to the background above, thus, the problems in this research are formulated as follows:

1) What is the response of non-Muslim students on educational environment in Muhammadiyah Education University of Sorong?

2) What factors affect the perception of non-Muslim students on educational environment in Muhammadiyah Education University of Sorong?

3) What obstacles faced by non-Muslim students on education environment in Muhammadiyah Education University of Sorong?

4) What efforts should be done to overcome the obstacle of non-Muslim students on educational environment in Muhammadiyah Education University of Sorong? 


\section{Literature Review}

\subsection{Perception}

In language, perception is the process of someone in knowing several things through the five senses (Poerwadarminta, 2006:880).

\subsection{Educational Environment}

According to Mohammad Surya, environment is any things stimulating individuals, thus, those individuals get involved and their growth are influenced by them (Surya, 2014). The National Education System Law No.20/2003 paragraph 1 verse 1 reads: Education is conscious and planned efforts to embody the learning atmosphere and process for the learning participants to actively develop their potential in having spiritual strengths and skills required by themselves, the community, nation, and state.

\subsection{The Perception of Non-Muslim Students on Educational Environment in Muhammadiyah Education University of Sorong}

As the part of charity ventures of Muhammadiyah Organization, Muhammadiyah Education University of Sorong refers to Muhammadiyah values which are based on Al Qur'an and As-Sunnah as well as the organization fundamental values that consist of: the Muqaddimah (introduction) of articles of Association, Muhammadiyah's Personality, Muhammadiyah's path of struggle (Khittah), Matn of Faith, and Muhammadiyah's life goals as well as the Islamic life guidance of Muhammadiyah's people. Basing on these values, Muhammadiyah Education University of Sorong is determined to make "Wacana Keilmuan dan Keislaman (Islamic and Scientific Notion)" as the philosophy for the establishment and development of higher education institution by attempting to integrate scientific and Islamic values, thus, the personality which masters sciences, technologies, and arts that imbued by Islamic values can be manifested (Renstra, 2013-2017).

\section{Research Method}

The procedures of this research consisted of three stages, namely the preparation of research instrument, the implementation of research, and the analysis of research results. Those stages are described as follows: 1. The preparation of research instrument in which a questionnaire was used in this study. 2. The implementation of research, after the instrument was collected in accordance with the expectation, the researcher began the study. The research was performed by disseminating the questionnaire pre-made by the researcher toward 180 nonMuslim students who became the sample in this study and recollecting the question after all students finished filling the made questionnaire. 3. The analysis of research results, after the study was done, the results of this study were analyzed through percentage technique from evaluators through the formulation pre-designed by the researcher.

The research was located in University Pendidikan Muhammadiyah Sorong because the majority of students in Muhammadiyah Education University of Sorong are Non-Muslims. There are 1,680 population of non-Muslim students in Muhammadiyah Education University of Sorong. Seeing from the taken population, thus, this research took sample through stratified random sampling technique, while the sample in this research was taken through Slovin's formula with $10 \%$ critical value (Prasetyo et al, 2010), the formula is as follows: 


$$
\begin{aligned}
& \mathrm{n}=\mathrm{N} / 1+\mathrm{Ne}^{2} \\
& \mathrm{n}=1.680 / 1+1.680 .(0,01) \\
& \mathrm{n}=1.680 / 17.8=94---100
\end{aligned}
$$

Information: $\mathrm{n}=$ sample size $\mathrm{N}=$ population size $\mathrm{e}=$ percentage of uncertainty tolerance due to the error of the sample collection which can still be tolerated is $10 \%$. Of the sample measurement result above, 94 people were taken as the minimum sample, however, this research rounded the respondent to 100 people to be studied.

The research variables used in this study were the perception of non-Muslim students, and educational environment. The approach model used in this research was a quantitative approach. Quantitative research as proposed by (Sugiyono, 2014). The design of this research included as a descriptive study, namely the study conducted to discover the value of independent variables, either one or more (independent) without making comparison, or connecting them with other variables (Sugiyono, 2014).

The data collecting in this research used several techniques, this effort meant to acquire comprehensive data as follows: 1 . Documentation technique, the documentation in this research was used to collect the data of the number of student in Muhammadiyah Education University of Sorong, and several elements that can be used in this research. 2. Questionnaire technique, the definition of questionnaire according to (Sugiyono, 2014) is a data collecting technique done by providing a set of questions or written questions toward the respondent to be answered.

This research used data analysis in descriptive-statistics manner as the analysis to discover the studied description based on data of the acquired variable. After that, data were analyzed by using crosstabs to discover the trend of the relationship between variables. The descriptive analysis result is usually presented in frequency and percentage, crosstabs, various forms of graphic and chart on categorical data as well as group statistics such as mean (Azwar, 2012). The categorization of scores of each aspect then be grouped into three categories. The categorization is done based on ideal mean (M) and standard of deviation (SD) on each aspect (Azwar, 2012), dividing the trend of each aspect into three categories as follows:

Table 1. The Guideline of Categorization

\begin{tabular}{lll}
\hline No & Category & Score \\
\hline 1 & High & $\mathrm{X} \geq \mathrm{M}+\mathrm{SD}$ \\
2 & Medium & $\mathrm{M}-\mathrm{SD} \leq \mathrm{X}<\mathrm{M}+\mathrm{SD}$ \\
3 & Low & $\mathrm{X}<\mathrm{M}-\mathrm{SD}$ \\
\hline
\end{tabular}

Information:

$\mathrm{M}($ Ideal Mean $)=1 / 2($ highest score + lowest score $)$

$\mathrm{SD}($ Ideal Standard of Deviation $)=1 / 6$ (highest score - lowest score)

$\mathrm{X}=$ The score achieved by the participant

Then, the method to determine the data analysis is by finding the amount of relative percentage with a formula as follows:

$\mathrm{P}=\mathrm{f} / \mathrm{N}$ x $100 \%$; Information: P: Percentage F: Frequency N: Total Population 


\section{The Discussion of Research Result}

4.1. The response of non-Muslim students on the environment of Muhammadiyah Education University of Sorong

1. Lecturers allow me to pray based on my religion and belief in the beginning of lectures in Universitas Muhammadiyah Education University of Sorong

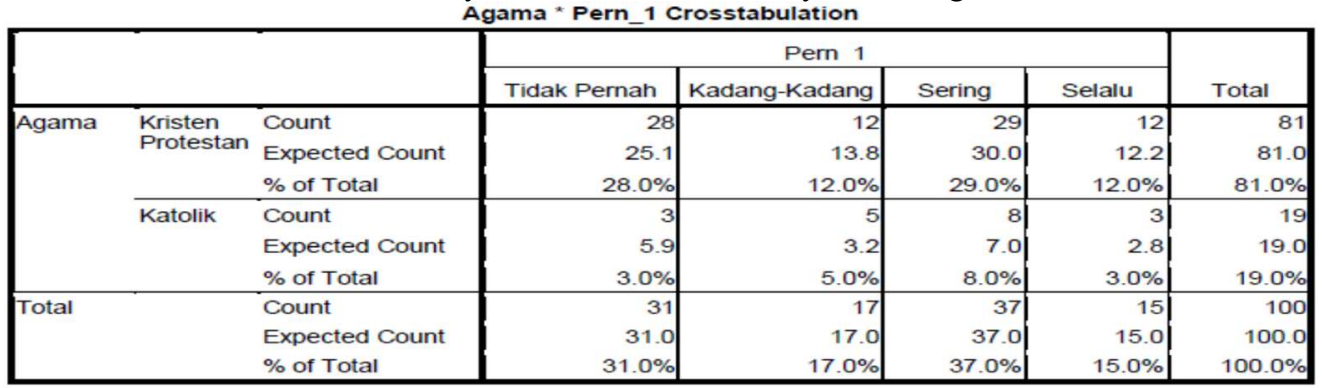

Of the result of crosstab above, it can be concluded that most of the protestant and catholic students as the respondent are choosing "often" as the answer regarding the statement; lecturers allow me to pray based on my religion and belief during in the beginning of lectures in Muhammadiyah Education University of Sorong

2. I receive the quality of learning which equal to other students from lecturers in Muhammadiyah Education University of Sorong

\begin{tabular}{|c|c|c|c|c|c|c|c|}
\hline & & & \multicolumn{4}{|c|}{ Pern 2} & \multirow[b]{2}{*}{ Total } \\
\hline & & & Tidak pernah & Kadang-Kadang & Sering & Selalu & \\
\hline \multirow[t]{6}{*}{ Agama } & \multirow{3}{*}{$\begin{array}{l}\text { Kristen } \\
\text { Protestan }\end{array}$} & Count & 6 & 3 & 15 & 57 & 81 \\
\hline & & Expected Count & 5.7 & 3.2 & 14.6 & 57.5 & 81.0 \\
\hline & & $\%$ of Total & $6.0 \%$ & $3.0 \%$ & $15.0 \%$ & $57.0 \%$ & $81.0 \%$ \\
\hline & \multirow[t]{3}{*}{ Katolik } & Count & 1) & 1 & 3 & 14 & 19 \\
\hline & & Expected Count & 1.3 & 8 & 3.4 & 13.5 & 19.0 \\
\hline & & $\%$ of Total & $1.0 \%$ & $1.0 \%$ & $3.0 \%$ & $14.0 \%$ & $19.0 \%$ \\
\hline \multirow[t]{3}{*}{ Total } & & Count & 7 & 4 & 18 & 71 & 100 \\
\hline & & Expected Count & 7.0 & 4.0 & 18.0 & 71.0 & 100.0 \\
\hline & & $\%$ of Total & $7.0 \%$ & $4.0 \%$ & $18.0 \%$ & $71.0 \%$ & $100.0 \%$ \\
\hline
\end{tabular}

Of the result of crosstab above, it can be concluded that most of the protestant and catholic students as the respondent are choosing "always" as the answer regarding the statement; I receive the quality of learning which equal to other students from lecturers in Muhammadiyah Education University of Sorong

3. In Muhammadiyah Education University of Sorong, I receive the lecturing service from lecturers with polite ethics and personalities 


\begin{tabular}{|c|c|c|c|c|c|c|c|}
\hline & & & \multicolumn{4}{|c|}{ Pern 3} & \multirow[b]{2}{*}{ Total } \\
\hline & & & Tidak Pernah & Kadang-Kadang & Sering & Selalu & \\
\hline \multirow[t]{6}{*}{ Agama } & \multirow{3}{*}{$\begin{array}{l}\text { Kristen } \\
\text { Protestan }\end{array}$} & Count & 1 & 1 & 11 & 68 & 81 \\
\hline & & Expected Count & .8 & 1.6 & 8.9 & 69.7 & 81.0 \\
\hline & & $\%$ of Total & $1.0 \%$ & $1.0 \%$ & $11.0 \%$ & $68.0 \%$ & $81.0 \%$ \\
\hline & \multirow[t]{3}{*}{ Katolik } & Count & 0 & 1 & 이 & 18 & 19 \\
\hline & & Expected Count & .2 & .4 & 2.1 & 16.3 & 19.0 \\
\hline & & $\%$ of Total & $.0 \%$ & $1.0 \%$ & $.0 \%$ & $18.0 \%$ & $19.0 \%$ \\
\hline \multirow[t]{3}{*}{ Total } & & Count & 1 & 2 & 11] & 86] & 100 \\
\hline & & Expected Count & 1.0 & 2.0 & 11. 이 & 86.0 & 100.0 \\
\hline & & $\%$ of Total & $1.0 \%$ & $2.0 \%$ & $11.0 \%$ & $86.0 \%$ & $100.0 \%$ \\
\hline
\end{tabular}

Of the result of crosstab above, it can be concluded that most of the protestant and catholic students as the respondent are choosing "always" as the answer regarding the statement; in Muhammadiyah Education University of Sorong, I receive the lecturing service from lecturers with polite ethics and personalities.

4. In Muhammadiyah Education University of Sorong, I receive administration services from staffs with polite ethics and personalities

\begin{tabular}{|c|c|c|c|c|c|c|c|}
\hline & & & \multicolumn{4}{|c|}{ Pern_4 } & \multirow[b]{2}{*}{ Total } \\
\hline & & & Tidak Pernah & Kadang-Kadang & Sering & Selalu & \\
\hline \multirow[t]{6}{*}{ Agama } & \multirow{3}{*}{$\begin{array}{l}\text { Kristen } \\
\text { Protestan }\end{array}$} & Count & 5 & 8 & 8 & 60 & 81 \\
\hline & & Expected Count & 4.0 & 7.3 & 6.5 & 63.2 & 81.0 \\
\hline & & $\%$ of Total & $5.0 \%$ & $8.0 \%$ & $8.0 \%$ & $60.0 \%$ & $81.0 \%$ \\
\hline & \multirow[t]{3}{*}{ Katolik } & Count & 이 & 1 & 이 & 18 & 19 \\
\hline & & Expected Count & 1.0 & 1.7 & 1.5 & 14.8 & 19.0 \\
\hline & & $\%$ of Total & $.0 \%$ & $1.0 \%$ & $.0 \%$ & $18.0 \%$ & $19.0 \%$ \\
\hline \multirow[t]{3}{*}{ Total } & & Count & 5 & 9 & 8 & 78 & 100 \\
\hline & & Expected Count & 5.0 & 9.0 & 8.0 & 78.0 & 100.0 \\
\hline & & $\%$ of Total & $5.0 \%$ & $9.0 \%$ & $8.0 \%$ & $78.0 \%$ & $100.0 \%$ \\
\hline
\end{tabular}

Of the result of crosstab above, it can be concluded that most of the protestant and catholic students as the respondent are choosing "always" as the answer regarding the statement; in Muhammadiyah Education University of Sorong, I receive administration services from staffs with polite ethics and personalities.

5. In Muhammadiyah Education University of Sorong, I receive Facility and Infrastructure services from staffs with polite ethics and personalities.

\begin{tabular}{|c|c|c|c|c|c|c|c|}
\hline & & & \multicolumn{4}{|c|}{ Pern_5 } & \multirow[b]{2}{*}{ Total } \\
\hline & & & Tidak Pernah & Kadang-Kadang & Sering & Selalu & \\
\hline \multirow[t]{6}{*}{ Agama } & \multirow{3}{*}{$\begin{array}{l}\text { Kristen } \\
\text { Protestan }\end{array}$} & Count & 6 & 12 & 14 & 49 & 81 \\
\hline & & Expected Count & 5.7 & 10.5 & 13.8 & 51.0 & 81.0 \\
\hline & & $\%$ of Total & $6.0 \%$ & $12.0 \%$ & $14.0 \%$ & $49.0 \%$ & $81.0 \%$ \\
\hline & \multirow[t]{3}{*}{ Katolik } & Count & 1 & 1 & 3) & 14 & 19 \\
\hline & & Expected Count & 1.3 & 2.5 & 3.2 & 12.0 & 19.0 \\
\hline & & $\%$ of Total & $1.0 \%$ & $1.0 \%$ & $3.0 \%$ & $14.0 \%$ & $19.0 \%$ \\
\hline \multirow[t]{3}{*}{ Total } & & Count & 7 & 13 & 17| & 63 & 100 \\
\hline & & Expected Count & 7.0 & 13.0 & 17.0 & 63.0 & 100.0 \\
\hline & & $\%$ of Total & $7.0 \%$ & $13.0 \%$ & $17.0 \%$ & $63.0 \%$ & $100.0 \%$ \\
\hline
\end{tabular}

Of the result of crosstab above, it can be concluded that most of the protestant and catholic students as the respondent are choosing "always" as the answer regarding the 
statement; in Muhammadiyah Education University of Sorong, I receive Facility and Infrastructure services from staffs with polite ethics and personalities.

6. In Muhammadiyah Education University of Sorong, I am helped when facing academic issues by Academic Advisors with polite ethics and personalities.

\begin{tabular}{|c|c|c|c|c|c|c|c|}
\hline & & & \multicolumn{4}{|c|}{ Pern 6} & \multirow[b]{2}{*}{ Total } \\
\hline & & & Tidak Pernah & Kadang-Kadanq & Sering & Selalu & \\
\hline \multirow[t]{6}{*}{ Agama } & \multirow{3}{*}{$\begin{array}{l}\text { Kristen } \\
\text { Protestan }\end{array}$} & Count & 14 & 20 & 13 & 34 & 81 \\
\hline & & Expected Count & 12.2 & 18.6 & 13.이 & 37.3 & 81.0 \\
\hline & & $\%$ of Total & $14.0 \%$ & $20.0 \%$ & $13.0 \%$ & $34.0 \%$ & $81.0 \%$ \\
\hline & \multirow[t]{3}{*}{ Katolik } & Count & 1 & 3 & 3) & 12 & 19 \\
\hline & & Expected Count & 2.8 & 4.4 & 3.이 & 8.7 & 19.0 \\
\hline & & $\%$ of Total & $1.0 \%$ & $3.0 \%$ & $3.0 \%$ & $12.0 \%$ & $19.0 \%$ \\
\hline \multirow[t]{3}{*}{ Total } & & Count & 15 & 23 & 16 & 46 & 100 \\
\hline & & Expected Count & 15.0 & 23.0 & 16.0 & 46.0 & 100.0 \\
\hline & & $\%$ of Total & $15.0 \%$ & $23.0 \%$ & $16.0 \%$ & $46.0 \%$ & $100.0 \%$ \\
\hline
\end{tabular}

Of the result of crosstab above, it can be concluded that most of the protestant and catholic students as the respondent are choosing "always" as the answer regarding the statement; in Muhammadiyah Education University of Sorong, I am helped when facing academic issues by Academic Advisors with polite ethics and personalities.

7. In Muhammadiyah Education University of Sorong, I receive free health services via Ibnu Sina Clinic of Muhammadiyah Education University of Sorong

\begin{tabular}{|c|c|c|c|c|c|c|c|}
\hline & & & \multicolumn{4}{|c|}{ Pern_7 } & \multirow[b]{2}{*}{ Total } \\
\hline & & & Tidak Pernah & Kadang-Kadang & Sering & Selalu & \\
\hline \multirow[t]{6}{*}{ Agama } & \multirow{3}{*}{$\begin{array}{l}\text { Kristen } \\
\text { Protestan }\end{array}$} & Count & 32 & 15 & 12 & 22 & 81 \\
\hline & & Expected Count & 32.4 & 16.2 & 9.7| & 22.7 & 81.0 \\
\hline & & $\%$ of Total & $32.0 \%$ & $15.0 \%$ & $12.0 \%$ & $22.0 \%$ & $81.0 \%$ \\
\hline & \multirow[t]{3}{*}{ Katolik } & Count & 8 & 5 & 이 & 6 & 19 \\
\hline & & Expected Count & 7.6 & 3.8 & 2.3. & 5.3 & 19.0 \\
\hline & & $\%$ of Total & $8.0 \%$ & $5.0 \%$ & $.0 \%$ & $6.0 \%$ & $19.0 \%$ \\
\hline \multirow[t]{3}{*}{ Total } & & Count & 40 & 20 & 12 & 28 & 100 \\
\hline & & Expected Count & 40.0 & 20.0 & 12.0 & 28.0 & 100.0 \\
\hline & & $\%$ of Total & $40.0 \%$ & $20.0 \%$ & $12.0 \%$ & $28.0 \%$ & $100.0 \%$ \\
\hline
\end{tabular}

Of the result of crosstab above, it can be concluded that most of the protestant and catholic students as the respondent are choosing "never" as the answer regarding the statement; in Muhammadiyah Education University of Sorong, I receive free health services via Ibnu Sina Clinik of Muhammadiyah Education University of Sorong.

8. In Muhammadiyah Education University of Sorong, I receive equal services regarding internships at Labschool primary school, junior high school, and senior high school by Muhammadiyah Education University of Sorong 


\begin{tabular}{|c|c|c|c|c|c|c|c|}
\hline & & & \multicolumn{4}{|c|}{ Pern_8 } & \multirow[b]{2}{*}{ Total } \\
\hline & & & Tidak Pernah & Kadang-Kadang & Sering & Selalu & \\
\hline \multirow[t]{6}{*}{ Agama } & \multirow{3}{*}{$\begin{array}{l}\text { Kristen } \\
\text { Protestan }\end{array}$} & Count & 29 & 7 & 13 & 32 & 81 \\
\hline & & Expected Count & 27.5 & 6.5 & 13.이 & 34.0 & 81.0 \\
\hline & & $\%$ of Total & $29.0 \%$ & $7.0 \%$ & $13.0 \%$ & $32.0 \%$ & $81.0 \%$ \\
\hline & \multirow[t]{3}{*}{ Katolik } & Count & 5 & 1 & 3) & 10 & 19 \\
\hline & & Expected Count & 6.5 & 1.5 & 3.이 & 8.0 & 19.0 \\
\hline & & $\%$ of Total & $5.0 \%$ & $1.0 \%$ & $3.0 \%$ & $10.0 \%$ & $19.0 \%$ \\
\hline \multirow[t]{3}{*}{ Total } & & Count & 34 & 8 & 16] & 42 & 100 \\
\hline & & Expected Count & 34.0 & 8.0 & 16.이 & 42.0 & 100.0 \\
\hline & & $\%$ of Total & $34.0 \%$ & $8.0 \%$ & $16.0 \%$ & $42.0 \%$ & $100.0 \%$ \\
\hline
\end{tabular}

Of the result of crosstab above, it can be concluded that most of the protestant and catholic students as the respondent are choosing "always" as the answer regarding the statement; in Muhammadiyah Education University of Sorong, I receive equal services regarding internships at Labschool primary school, junior high school, and senior high school by Muhammadiyah Education University of Sorong.

9. In Muhammadiyah Education University of Sorong, I receive financial services from staffs with polite ethics and personalities.

\begin{tabular}{|c|c|c|c|c|c|c|c|}
\hline \multicolumn{8}{|c|}{ Agama * Pern_9 Crosstabulation } \\
\hline & & & \multicolumn{4}{|c|}{ Pern_9 } & \multirow[b]{2}{*}{ Total } \\
\hline & & & Tidak Pernah & Kadang-Kadang & Sering & Selalu & \\
\hline \multirow[t]{6}{*}{ Agama } & \multirow{3}{*}{$\begin{array}{l}\text { Kristen } \\
\text { Protestan }\end{array}$} & Count & 15 & 12 & 10 & 44 & 81 \\
\hline & & Expected Count & 14.6 & 9.7 & 8.9 & 47.8 & 81.0 \\
\hline & & $\%$ of Total & $15.0 \%$ & $12.0 \%$ & $10.0 \%$ & $44.0 \%$ & $81.0 \%$ \\
\hline & \multirow[t]{3}{*}{ Katolik } & Count & 3 & o & 1 & 15 & 19 \\
\hline & & Expected Count & 3.4 & 2.3 & 2.1 & 11.2 & 19.0 \\
\hline & & $\%$ of Total & $3.0 \%$ & $.0 \%$ & $1.0 \%$ & $15.0 \%$ & $19.0 \%$ \\
\hline \multirow[t]{3}{*}{ Total } & & Count & 18 & 12 & 11 & 59 & 100 \\
\hline & & Expected Count & 18.0 & 12.0 & 11.0 & 59.0 & 100.0 \\
\hline & & $\%$ of Total & $18.0 \%$ & $12.0 \%$ & $11.0 \%$ & $59.0 \%$ & $100.0 \%$ \\
\hline
\end{tabular}

Of the result of crosstab above, it can be concluded that most of the protestant and catholic students as the respondent are choosing "always" as the answer regarding the statement; in Muhammadiyah Education University of Sorong, I receive financial services from staffs with polite ethics and personalities.

10. In Muhammadiyah Education University of Sorong, I receive library services from staffs with polite ethics and personalities.

\begin{tabular}{|c|c|c|c|c|c|c|c|}
\hline & & & \multicolumn{4}{|c|}{ Pern 10} & \multirow[b]{2}{*}{ Total } \\
\hline & & & Tidak Pernah & Kadang-Kadang & Sering & Selalu & \\
\hline \multirow[t]{6}{*}{ Agama } & \multirow{3}{*}{$\begin{array}{l}\text { Kristen } \\
\text { Protestan }\end{array}$} & Count & 10 & 23 & 14 & 34 & 81 \\
\hline & & Expected Count & 9.7 & 24.3 & 13.8 & 33.2 & 81.0 \\
\hline & & $\%$ of Total & $10.0 \%$ & $23.0 \%$ & $14.0 \%$ & $34.0 \%$ & $81.0 \%$ \\
\hline & \multirow[t]{3}{*}{ Katolik } & Count & 2 & 7 & 3) & 7 & 19 \\
\hline & & Expected Count & 2.3 & 5.7 & 3.2 & 7.8 & 19.0 \\
\hline & & $\%$ of Total & $2.0 \%$ & $7.0 \%$ & $3.0 \%$ & $7.0 \%$ & $19.0 \%$ \\
\hline \multirow[t]{3}{*}{ Total } & & Count & 12 & 30 & 17 & 41 & 100 \\
\hline & & Expected Count & 12.0 & 30.0 & 17.0 & 41.0 & 100.0 \\
\hline & & $\%$ of Total & $12.0 \%$ & $30.0 \%$ & $17.0 \%$ & $41.0 \%$ & $100.0 \%$ \\
\hline
\end{tabular}


Of the result of crosstab above, it can be concluded that most of the protestant and catholic students as the respondent are choosing "always" as the answer regarding the statement; in Muhammadiyah Education University of Sorong, I receive library services from staffs with polite ethics and personalities.

11. In Muhammadiyah Education University of Sorong, I receive the quality of learning which equal to other students from Arabic Lecturer.

Agama * Pern_11 Crosstabulation

\begin{tabular}{|c|c|c|c|c|c|c|c|}
\hline & & & \multicolumn{4}{|c|}{ Pern_11 } & \multirow[b]{2}{*}{ Total } \\
\hline & & & Tidak Pernah & Kadanq-Kadang & Sering & Selalu & \\
\hline \multirow[t]{6}{*}{ Agama } & \multirow{3}{*}{$\begin{array}{l}\text { Kristen } \\
\text { Protestan }\end{array}$} & Count & 3 & 11 & 14 & 53 & 81 \\
\hline & & Expected Count & 4.9 & 8.9 & 13.이 & 54.3 & 81.0 \\
\hline & & $\%$ of Total & $3.0 \%$ & $11.0 \%$ & $14.0 \%$ & $53.0 \%$ & $81.0 \%$ \\
\hline & \multirow[t]{3}{*}{ Katolik } & Count & 3 & 0 & 21 & 14 & 19 \\
\hline & & Expected Count & 1.1 & 2.1 & 3.이 & 12.7 & 19.0 \\
\hline & & $\%$ of Total & $3.0 \%$ & $.0 \%$ & $2.0 \%$ & $14.0 \%$ & $19.0 \%$ \\
\hline \multirow[t]{3}{*}{ Total } & & Count & 6 & 11 & 16] & 67 & 100 \\
\hline & & Expected Count & 6.0 & 11.0 & 16.이 & 67.0 & 100.0 \\
\hline & & $\%$ of Total & $6.0 \%$ & $11.0 \%$ & $16.0 \%$ & $67.0 \%$ & $100.0 \%$ \\
\hline
\end{tabular}

Of the result of crosstab above, it can be concluded that most of the protestant and catholic students as the respondent are choosing "always" as the answer regarding the statement; in Muhammadiyah Education University of Sorong, I receive the quality of learning which equal to other students from Arabic Lecturer.

In Muhammadiyah Education University of Sorong, I receive student services regarding scholarships through student bureau with polite ethics and personalities.

\begin{tabular}{|c|c|c|c|c|c|c|c|}
\hline \multicolumn{7}{|c|}{ Pern 12} & \multirow[b]{2}{*}{ Total } \\
\hline & & & Tidak Pernah & Kadang-Kadang & Sering & Selalu & \\
\hline \multirow[t]{6}{*}{ Agama } & \multirow{3}{*}{$\begin{array}{l}\text { Kristen } \\
\text { Protestan }\end{array}$} & Count & 21 & 13 & 10 & 37 & 81 \\
\hline & & Expected Count & 18.6 & 11.3 & 12.2 & 38.9 & 81.0 \\
\hline & & $\%$ of Total & $21.0 \%$ & $13.0 \%$ & $10.0 \%$ & $37.0 \%$ & $81.0 \%$ \\
\hline & \multirow[t]{3}{*}{ Katolik } & Count & 2 & 1 & 5 & 11 & 19 \\
\hline & & Expected Count & 4.4 & 2.7 & 2.8 & 9.1 & 19.0 \\
\hline & & $\%$ of Total & $2.0 \%$ & $1.0 \%$ & $5.0 \%$ & $11.0 \%$ & $19.0 \%$ \\
\hline \multirow[t]{3}{*}{ Total } & & Count & 23 & 14 & 15) & 48 & 100 \\
\hline & & Expected Count & 23.0 & 14.0 & 15.0 & 48.0 & 100.0 \\
\hline & & $\%$ of Total & $23.0 \%$ & $14.0 \%$ & $15.0 \%$ & $48.0 \%$ & $100.0 \%$ \\
\hline
\end{tabular}

Of the result of crosstab above, it can be concluded that most of the protestant and catholic students as the respondent are choosing "always" as the answer regarding the statement; in Muhammadiyah Education University of Sorong, I receive student services regarding scholarships through student bureau with polite ethics and personalities.

12. In Muhammadiyah Education University of Sorong, I receive security services from securities with polite ethics and personalities. Agama * Pern_13 Crosstabulation 


\begin{tabular}{|c|c|c|c|c|c|c|c|}
\hline & & & \multicolumn{4}{|c|}{ Pern_13 } & \multirow[b]{2}{*}{ Total } \\
\hline & & & Tidak Pernah & Kadanq-Kadang & Sering & Selalu & \\
\hline \multirow[t]{6}{*}{ Agama } & \multirow{3}{*}{$\begin{array}{l}\text { Kristen } \\
\text { Protestan }\end{array}$} & Count & 15 & 14 & 9 & 43 & 81 \\
\hline & & Expected Count & 13.8 & 14.6 & 10.5 & 42.1 & 81.0 \\
\hline & & $\%$ of Total & $15.0 \%$ & $14.0 \%$ & $9.0 \%$ & $43.0 \%$ & $81.0 \%$ \\
\hline & \multirow[t]{3}{*}{ Katolik } & Count & 2 & 4 & 4 & 9 & 19 \\
\hline & & Expected Count & 3.2 & 3.4 & 2.5 & 9.9 & 19.0 \\
\hline & & $\%$ of Total & $2.0 \%$ & $4.0 \%$ & $4.0 \%$ & $9.0 \%$ & $19.0 \%$ \\
\hline \multirow[t]{3}{*}{ Total } & & Count & 17 & 18 & 13 & 52 & 100 \\
\hline & & Expected Count & 17.0 & 18.0 & 13.이 & 52.0 & 100.0 \\
\hline & & $\%$ of Total & $17.0 \%$ & $18.0 \%$ & $13.0 \%$ & $52.0 \%$ & $100.0 \%$ \\
\hline
\end{tabular}

Of the result of crosstab above, it can be concluded that most of the protestant and catholic students as the respondent are choosing "always" as the answer regarding the statement; In Muhammadiyah Education University of Sorong, I receive security services from securities with polite ethics and personalities

13. In Muhammadiyah Education University of Sorong, I receive equal opportunities to participate in organizations either it's BEM, DPM, HMJ, or IMM.

\begin{tabular}{|c|c|c|c|c|c|c|c|}
\hline & & & \multicolumn{4}{|c|}{ Pern_14 } & \multirow[b]{2}{*}{ Total } \\
\hline & & & Tidak Pernah & Kadang-Kadang & Sering & Selalu & \\
\hline \multirow[t]{6}{*}{ Agama } & \multirow{3}{*}{$\begin{array}{l}\text { Kristen } \\
\text { Protestan }\end{array}$} & Count & 27 & 8 & 9 & 37 & 81 \\
\hline & & Expected Count & 25.1 & 8.1 & 7.3 & 40.5 & 81.0 \\
\hline & & $\%$ of Total & $27.0 \%$ & $8.0 \%$ & $9.0 \%$ & $37.0 \%$ & $81.0 \%$ \\
\hline & \multirow[t]{3}{*}{ Katolik } & Count & 4 & 2 & 0 & 13 & 19 \\
\hline & & Expected Count & 5.9 & 1.9 & 1.7 & 9.5 & 19.0 \\
\hline & & $\%$ of Total & $4.0 \%$ & $2.0 \%$ & $.0 \%$ & $13.0 \%$ & $19.0 \%$ \\
\hline \multirow[t]{3}{*}{ Total } & & Count & 31 & 10 & 9 & $50 \mid$ & 100 \\
\hline & & Expected Count & 31.0 & 10.0 & 9.0 & 50.0 & 100.0 \\
\hline & & $\%$ of Total & $31.0 \%$ & $10.0 \%$ & $9.0 \%$ & $50.0 \%$ & $100.0 \%$ \\
\hline
\end{tabular}

Of the result of crosstab above, it can be concluded that most of the protestant and catholic students as the respondent are choosing "always" as the answer regarding the statement; In Muhammadiyah Education University of Sorong, I receive equal opportunities to participate in organizations either it's BEM, DPM, HMJ, or IMM.

14. In Muhammadiyah Education University of Sorong, I receive a clean, lovely, and enlightening campus service.

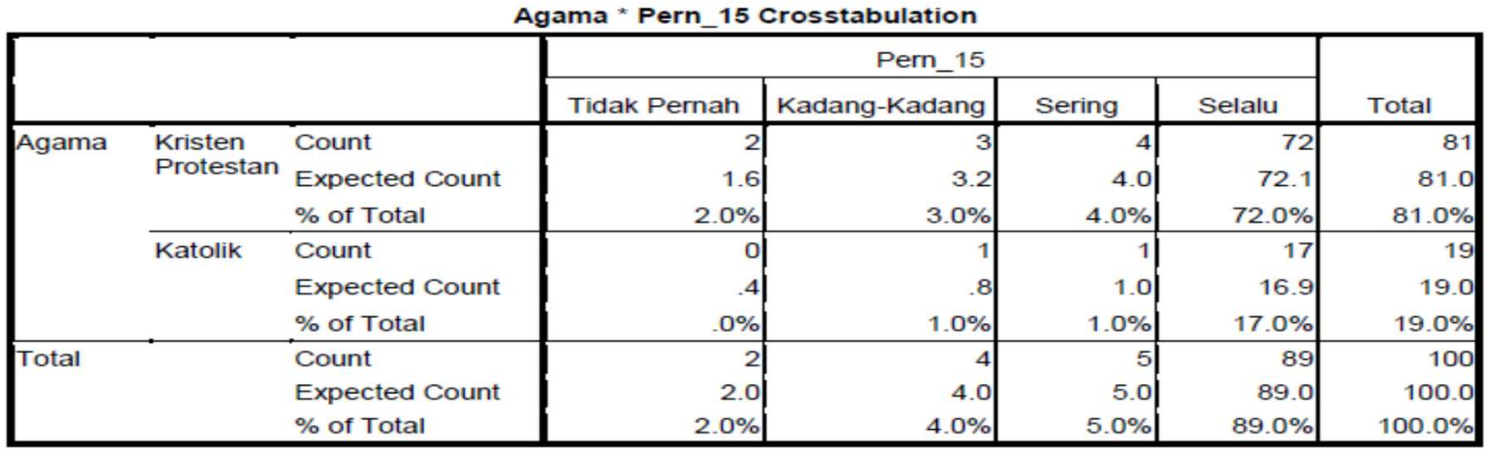


Of the result of crosstab above, it can be concluded that most of the protestant and catholic students as the respondent are choosing "always" as the answer regarding the statement; In Muhammadiyah Education University of Sorong, I receive a clean, lovely, and enlightening campus service.

4.2. The factor affecting the perception of non-Muslim students on educational environment in Muhammadiyah Education University of Sorong

According to the questionnaire distributed toward most of non-Muslim students of Muhammadiyah Education University of Sorong, they have given the answer in which the factor that affects the perception of non-Muslim students in the environment of Muhammadiyah Education University of Sorong is the openness of Muhammadiyah Education University of Sorong in accepting non-Muslim students by treating them equally to other students, in addition, non-Muslim students receive the privilege of having Christian subject, thus, non-Muslim students can learn their embraced religions.

4.3. The obstacle experienced by non-Muslim students during their study in Muhammadiyah Education University of Sorong along with the solution.

Based on the disseminated questionnaire, most of non-Muslim students in Muhammadiyah Education University of Sorong have answered that the obstacle faced during their study in Muhammadiyah Education University of Sorong is the expensive tuition fees, thus, this condition troubles them in completing their study in Muhammadiyah Education University of Sorong. According to Petrosnia Wanane (2017), the students of Pancasila and Civic Education Department stated that expensive tuition fees were the obstacle faced by them during their study in Muhammadiyah Education University of Sorong. Similar opinion has also expressed by the students of Primary Teacher Education Department, according to Juliana Wairasal (2017), the obstacle faced during the study in Muhammadiyah Education University of Sorong is the expensive tuition fees.

\subsection{The effort to overcome the obstacle faced by non-Muslim students on educational environment in Muhammadiyah Education University of Sorong}

According to the result of interview toward the Chief of Muhammadiyah Education University of Sorong, to overcome the issue of tuition fees experienced by non-Muslim students during their study, Muhammadiyah Education University of Sorong has established a policy in which the student who does not have money to pay off the tuition fee can pay the tuition fee in installment; provided that all the arrears are settled before the thesis exam. In addition, PPA, BBM, Bidikmisi, Adik Kakak Scholarship, and Santri Mahad Scholarship are also available to be applied. This policy will ease the students to continue and complete their study in Muhammadiyah Education University of Sorong.

\section{Conclusion and Recommendation}

\subsection{Conclusion}

The responses of non-Muslim students' perception on educational environment in Muhammadiyah Education University of Sorong were categorized as good, the factor affecting the perception of non-Muslim students on educational environment in Muhammadiyah Education University of Sorong was the openness of Muhammadiyah Education University of 
Sorong toward non-Muslim students, the obstacle faced by non-Muslim students toward educational environment in Muhammadiyah Education University of Sorong was the tuition fees, the effort to overcome the obstacle faced by non-Muslim toward the educational environment in Muhammadiyah Education University of Sorong is through the establishment of policies regarding tuition fees by Muhammadiyah Education University of Sorong

The results of a research regarding the perception of non-Muslim students toward the environment of Muhammadiyah Education University of Sorong can be concluded as follows: 1. the responses of non-Muslim students' perception on educational environment in Muhammadiyah Education University of Sorong were categorized as good. 2. the factor affecting the perception of non-Muslim students on educational environment in Muhammadiyah Education University of Sorong was the openness of Muhammadiyah Education University of Sorong toward non-Muslim students in providing education services. 3. the obstacle faced by non-Muslim students toward educational environment in Muhammadiyah Education University of Sorong was the tuition fees. 4. The effort to overcome the obstacle faced by non-Muslim students toward the educational environment in Muhammadiyah Education University of Sorong is the establishment of policy from Muhammadiyah Education University of Sorong to provide PPA, BBM, Bidikmisi, Adik Kakak Scholarship, and Santri Mahad Scholarship.

\subsection{Recommendation}

According to the conclusion mentioned above, thus, the revealed recommendations are as follows.

1. For lecturers of Muhammadiyah Education University of Sorong to continue improving the quality of teaching and learning process by not differentiating religions, races, in providing services toward students.

2. For the Bureau of Muhammadiyah Education University of Sorong to continue improving the service toward students with politeness.

3. For non-Muslim students of Muhammadiyah Education University of Sorong to be more critical and active in building the teaching and learning process in Muhammadiyah Education University of Sorong.

\section{References}

[1] Azwar, S. (2012). Penyusunan Skala Psikologi Edisi 2. Yogyakarta: Pustaka Pelajar.

[2] Hadi, A. (2008). Pendidikan (Suatu Pengantar). Surakarta: Lembaga Pengembangan Pendidikan (LPP) UNS dan UPT Penerbit dan Pencetakan UNS (UNS Press).

[3] Indriantoro, N. dan B. Supomo. (2009). Metodologi Penelitian Bisnis untuk Akuntansi dan Manajemen. Yogyakarta: Penerbit BPFE.

[4] Prasetyo, B. dan M. Jannah. (2010). Metode Penelitian Kuantitatif Teori dan Aplikasi. Jakarta: PT. Raja Grafindo Persada.

[5] Renstra, (2013-2017). Rencana Strategis Universitas Pendidikan Muhammadiyah Sorong

[6] Sugiyono. (2014). Metode Penelitian Kuantitatif, Kualitatif, dan R\&D. Bandung: Alfabeta.

[7] Surya, M. (2014). Psikologi Guru: Konsep Dan Aplikasinya. Bandung: ALFABETA CV. 